\title{
Development of typical flexible road pavement catalog for regional and intermunicipal highways in Russian Federation (using the example of the Republic of Bashkortostan)
}

\author{
Viktor Ushakov ${ }^{1 *}$, Mikhail Goryachev ${ }^{1}$, Sergey Lugov ${ }^{1}$, Andrey Kudryavtcev ${ }^{1}$ and Sergey \\ Yarkin $^{1}$ \\ ${ }^{1}$ Moscow Automobile and Road Construction State Technical University (MADI), Moscow, 125319, \\ Russia
}

\begin{abstract}
Road pavements in Russia are now working in difficult conditions of ever-growing vehicular traffic intensity. Current methodology for designing flexible road pavements has a number of serious shortcomings, where the best design experience and actual operating conditions of highways are not fully taken into account. In some cases, this leads to ineffective pavement structures design with a short service life. On many roads, rutting and premature wear of road surfaces appear already in the first years of their operation. Drainage systems are silted up in the first years of working. At the same time, geosynthetic materials are sometimes used unreasonably. The service life of roadway surfaces does not comply with the current regulations. In Russia, effective road-building materials are not yet fully used, local road-building materials and industrial waste reinforced with binders are little used. With exception of certain regions of the country, actual experience of operating various road structures with identification of the most optimal solutions is still poorly subject to consideration. Thus, there is an urgent need to develop designs of typical road pavements for various regions of Russia, which will ensure their efficient operation. To develop typical pavement designs, it is necessary to analyze existing ones in real conditions of their operation.
\end{abstract}

\section{Introduction}

The Republic of Bashkortostan occupies the 27th place in terms of area among the constituent entities of the Russian Federation, but at the same time it significantly exceeds area of many European countries. Such large regions of Russia have landscape, climatological, geological and resource specific features. For example, depth of freezing in the Republic of Bashkortostan territory ranges from $50 \mathrm{~cm}$ in central lowland part to 250 $\mathrm{cm}$ in mountainous areas. At the same time, many regulatory documents provide averaged design parameters for engineering structures design, which are not able to fully take into account a fairly wide range of design factors. In addition, developing projects for highways,

*Corresponding author: madi-ushakov@,mail.ru 
innovative road-building materials and advanced construction technologies are not always included in decisions made. Design errors have occurred. Therefore, in recent years, Russia has been actively developing books (catalogs) of designs for typical road pavements.

The effectiveness of the use of typical road pavement catalogs has been proven by the practice of Austria, Belgium, Germany, Italy, France, USA, China [2, 7, 8, 10, 19-21]. In Russia, typical landscape solutions are used in Moscow, St. Petersburg, Irkutsk, on federal and toll roads [13-15, 17].

An analysis of previously published typical road pavement catalogs demonstrates how the design of road pavements has developed: the used road building materials, including geosynthetic ones, have been improved, the thickness of surface and base layers has increased, and the account of operating conditions has been specified. This is what makes it possible today to develop high-tech and efficient typical road pavements.

The aim of the study is to develop a catalog of typical flexible road pavements that provides the required service life, taking into account modern and local road building materials used in the conditions of the Republic of Bashkortostan.

\section{Materials and methods}

The Republic of Bashkortostan territory is located in the III RBCZ (road building climatic zone) of the 1st subzone with significant change in the values of number of climatic parameters. At customer request, when developing a catalog of typical road pavements service life was taken equal to 12 years for roads of the categories II and III, 10 years for roads of the category IV. According to work plan, it was necessary to analyze road pavement structures on the roads in operation, to formulate principles for typical road pavement design based on international experience $[1,3-6,9,11,12,16,18,20]$ and to design those that meet modern trends, typical solutions, taking into account resource and production base characteristics and local construction organizations capabilities.

The basis of the research method and the development of recommendations for the design of flexible pavements is the analysis of statistical data on the design features of the most durable flexible pavements of highways in the Republic of Bashkortostan. The information obtained is collected and processed separately for surface course, base and subbase courses, as well as for wearing layers. Priority types of road building materials are established on roads of various categories, which characterize the specifics of design solutions in the region, the local market for road building materials (including geosynthetic materials and binders) and the priorities of construction contractors.

In order to analyze design solutions of operated flexible road pavements, study principles of designing flexible pavements in road and climatic conditions of the Republic of Bashkortostan and road building materials used, information was collected on design of flexible pavements on sections of regional and intermunicipal highways. As a result of 26 highways processing and analysis, basic principles of designing flexible road pavements in the Republic of Bashkortostan were established, as well as ways of structures improving that were used in development of book of typical pavements.

\section{Results}

Figs. 1...4 show some results of statistical analysis of road pavement design features of highways in the Republic of Bashkortostan.

Following application of road-building materials and design features of road pavements are noted: 
- All asphalt concrete is designed according to the old regulatory documents. Asphalt concrete designed according to modern regulatory documents is not used.

- Asphalt concrete mixtures preparation is carried out on viscous bitumen. PG grades bitumen are not used.

- Asphalt concrete reinforcement with polyester geogrids was recorded only in two cases.

- Only in one case there was separation of clay soil and an subbase course by geotextiles used.

- In one case, unreinforced stone materials were reinforced with a TriAx 160 geogrid.

- In most cases, stone materials and soils reinforced with binders are not used in bearing base courses.

- Only surface treatment is used as a protective layer.

- In subbase courses, sand and gravel mixtures are used, and not sands, which are used in many regions of Russia.

Analysis showed the need for and existing significant opportunities to improve road pavements design in the Republic of Bashkortostan to ensure standard service life and increase efficiency.

Fig. 1 shows the use of asphalt concrete of various types in road surfaces upper layers in the Republic of Bashkortostan. Attention is drawn to prevailing number of cases of type $B$ asphalt concrete use. Of five cases of stone-mastic asphalt use, four fall on the Ufa city.

Table 1 shows recommended areas of application in the upper layers of coatings (wear layers) of asphalt concrete various types. Fig. 2 illustrates relationship between asphalt concrete in the upper layers of pavement (wear layers) with and without polymer-modified binder. All cases of asphalt use based on polymer-bitumen binder are accounted for by stone-mastic asphalt concrete.

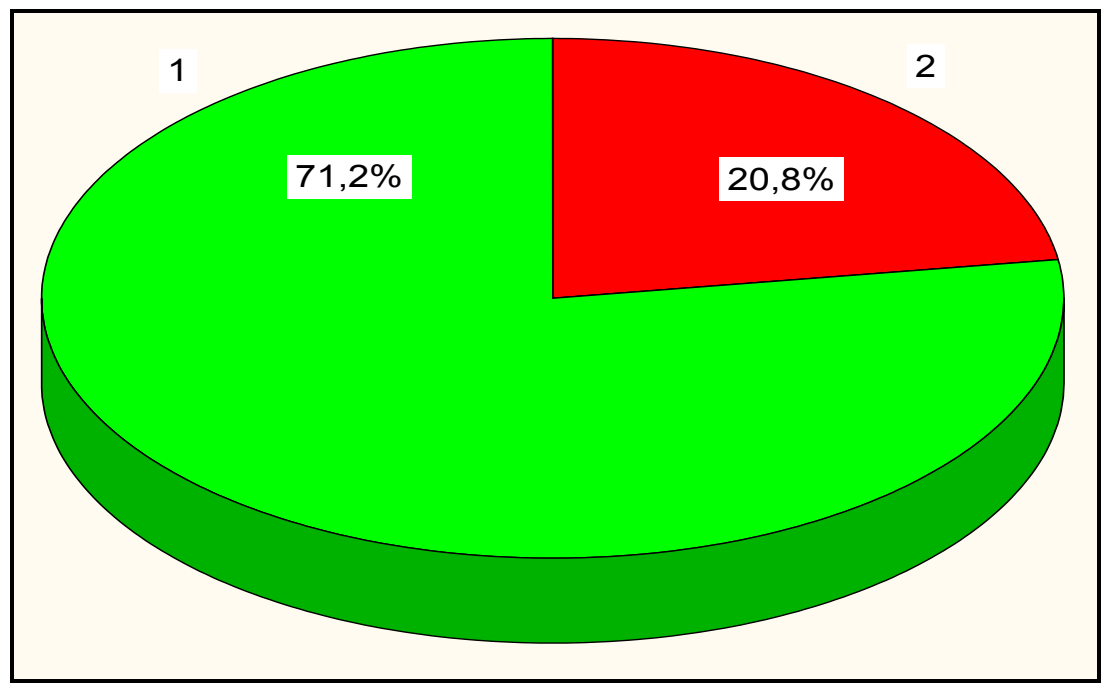

Fig. 1. Use of asphalt concrete of various types in the upper layers of coatings on regional and intermunicipal roads of the Republic of Bashkortostan and Ufa city: 1 - asphalt concrete type B; 2 - stone-mastic asphalt. 


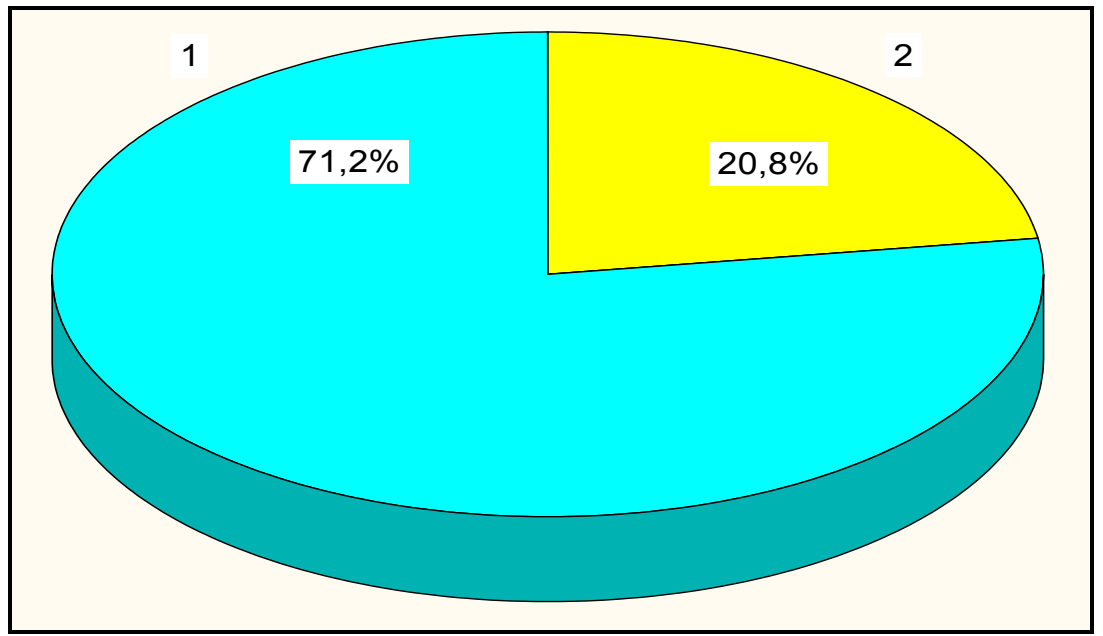

Fig. 2. Diagram of asphalt concrete with polymer bitumen binders use in construction of flexible road pavements on regional and intermunicipal roads in the Republic of Bashkortostan and Ufa city: 1 - asphalt concrete without PBB; 2 - asphalt concrete on PBB.

Table 1. Material purpose of the upper layer of coating (wear layer) for flexible pavements of regional and intermunicipal highways in the Republic of Bashkortostan.

\begin{tabular}{|c|c|c|}
\hline \multirow{2}{*}{$\begin{array}{c}\text { Road } \\
\text { category }\end{array}$} & Asphalt concrete type \\
\cline { 2 - 3 } & Stone-mastic asphalt & $\begin{array}{c}\text { Dense-graded asphalt concrete or } \\
\text { asphalt concrete according to } \\
\text { PNST 184-2019 }\end{array}$ \\
\hline II & + & - \\
\hline III & + & + \\
\hline IV & - & + \\
\hline
\end{tabular}

Note. "+" sign is recommended solution, "-" sign is an inexpedient solution.

Pavement structures with two layers of asphalt concrete cover are presented on all roads categories from sample (see Table 1): II, III, and IV, and with a single layer only on category IV (Table 2).

Table 2. The number of layers of asphalt concrete pavements on regional and intermunicipal roads in the Republic of Bashkortostan.

\begin{tabular}{|c|c|c|}
\hline \multirow{2}{*}{ Road category } & \multicolumn{2}{|c|}{ Number of roadway surfacing's } \\
\cline { 2 - 3 } & With one coating layer & With two coating layers \\
\hline II & 0 & 5 \\
\hline III & 0 & 4 \\
\hline IV & 5 & 12 \\
\hline
\end{tabular}

Pavement structures with one or two base layers are presented on all considered road categories with asphalt concrete pavements: II, III, and IV (Table 3). Prevailing number of cases with one bearing base layer falls on the category IV roads. For the category II 
highways, priority is given to two-layer load-bearing bases. Structures with one and two load-bearing base layers are presented in the same proportion on category III roads.

Table 3. The number of bearing layers of flexible road pavements bases on regional and intermunicipal roads in the Republic of Bashkortostan.

\begin{tabular}{|c|c|c|}
\hline \multirow{2}{*}{ Road category } & \multicolumn{2}{|c|}{ Number of roadway surfacing's } \\
\cline { 2 - 3 } & With one base layer & With two base layers \\
\hline II & 1 & 4 \\
\hline III & 2 & 2 \\
\hline IV & 11 & 6 \\
\hline
\end{tabular}

On the roads of the Republic of Bashkortostan, the following cases of constructive solutions with load-bearing base layers are used: with unreinforced bases (both single-layer and two-layer), with strengthening only upper base layer, with strengthening two base layers. Asphalt concrete and stone materials treated with cement grade M400, mainly applied in Ufa territory, are used as reinforced foundations. Ratio of cases of pavements with reinforced and unreinforced bases is shown in Fig. 3.

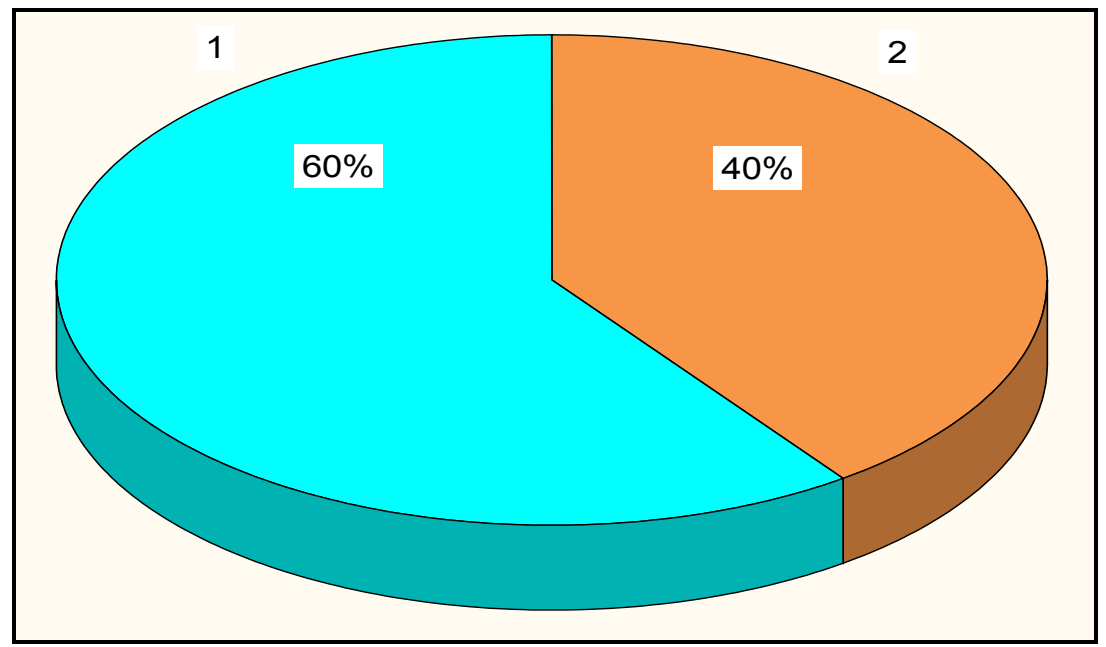

Fig. 3. Diagram of unreinforced and reinforced bases use of flexible road pavements on regional and intermunicipal highways of the Republic of Bashkortostan and Ufa city: 1 - without reinforced bases; 2 - with reinforced bases.

Fig. 4 shows percentage ratio of base layers, depending on stone materials used. It should be noted that, as additional base layers in the Republic of Bashkortostan, priority is given to sand and gravel mixtures and other types of stone materials (Fig. 5).

In a number of pavement designs, there are violations of design standards in terms of ensuring minimum thicknesses various materials layers (17 cases were noted). First of all, this applies to asphalt concrete layers. As the sociological survey has shown, this circumstance is partly caused by the dynamic improvement of the industry's regulatory framework and the lag behind the operational accounting of regulatory innovations in design practice. 


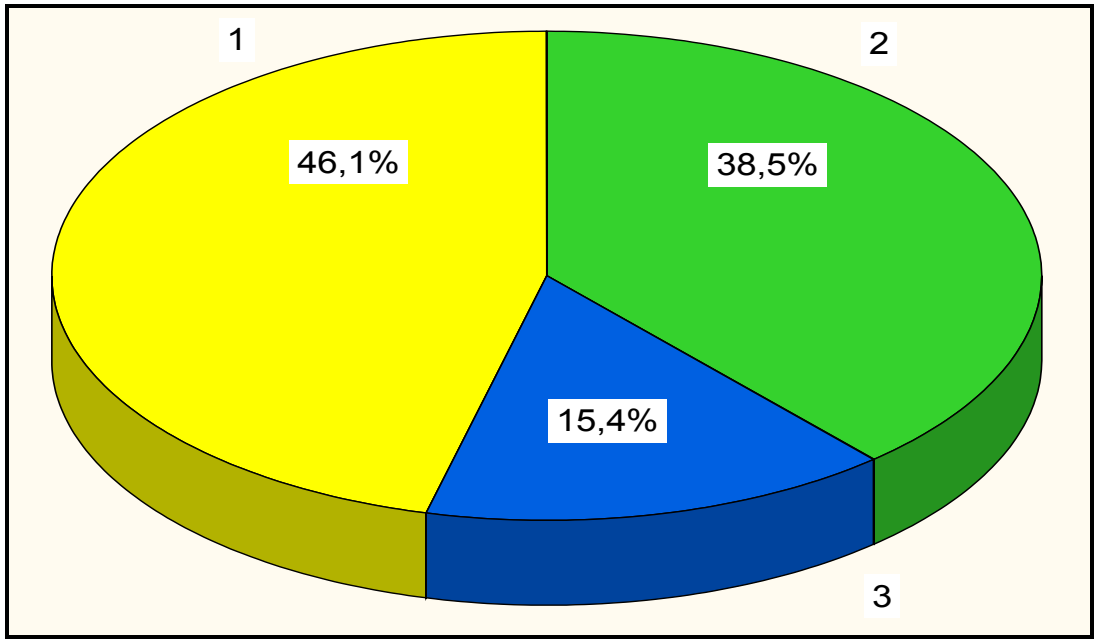

Fig. 4. Diagram of various unreinforced stone materials use in construction of bases bearing layers of flexible road pavements on regional and intermunicipal roads of the Republic of Bashkortostan and Ufa city:

1 - crushed stone by blocking method; 2 - fractionated crushed stone; 3 - stone materials mixtures.

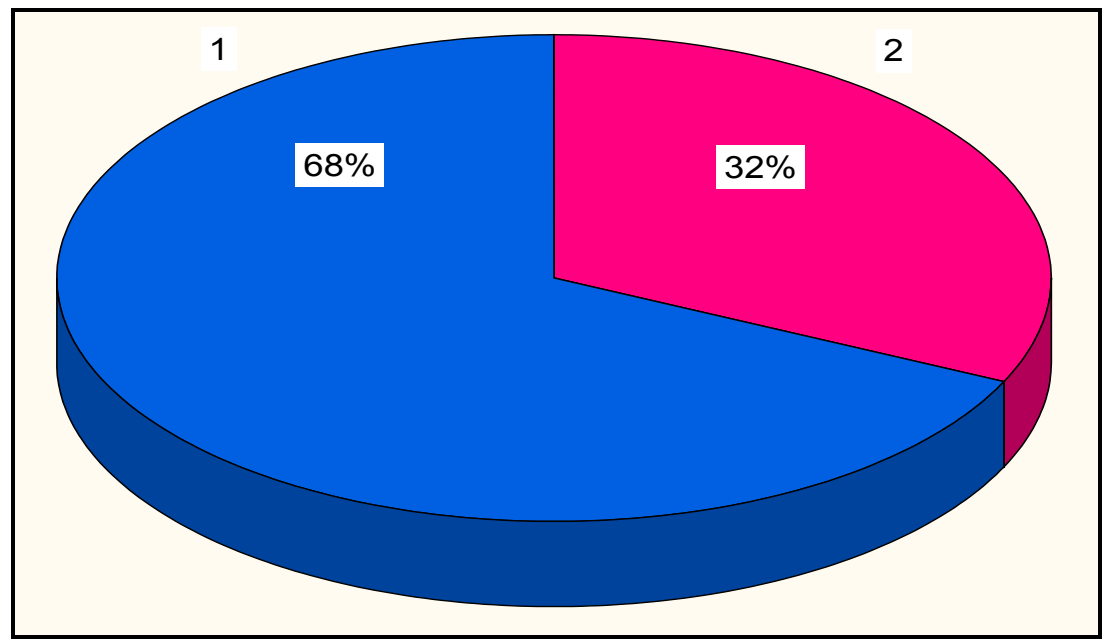

Fig. 5. Diagram of various materials use when constructing additional layers of bases for flexible road pavements on regional and intermunicipal highways in the Republic of Bashkortostan and Ufa city: 1 - sand and gravel mixtures; 2 - other stone materials.

When calculating and designing pavements, the following principles were applied:

- Standard load is assumed to be $115 \mathrm{kN}$ per axle for motor roads with permanent type of pavement and $100 \mathrm{kN}$ per axle for motor roads with lightweight and transitional types of pavement. Calculated specific pressure is taken equal to $0.8 \mathrm{MPa}$ for highways with permanent type of pavement and $0.6 \mathrm{MPa}$ for highways with lightweight and transitional types of pavement. At the same time, the study of the products of the automotive industry of leading foreign manufacturers leads to the conclusion that the calculated specific pressure of $0.8 \mathrm{MPa}$ does not correspond to the load of $115 \mathrm{kN}$. At loads of $115 \mathrm{kN}$, the calculated specific pressure is approximately $0.95 \mathrm{MPa}$ for twin wheels, which indicates a lag in Russian standards in terms of taking into account the actual load characteristics of modern vehicles. 
- The calculated modulus of subgrade working layer soil elasticity must be at least 40 MPa. High reliability and durability of road pavements will be ensured if the calculated modulus of elasticity of the subgrade working layer soil at least $40 \mathrm{MPa}$. This condition is dictated by the need to stabilize the values of moisture and density in the annual cycle, as well as to reduce the consequences of soil freezing. High values of strength characteristics in the zone of damping of active shear stresses contribute to a decrease in the amplitude of fluctuations in humidity and density. In addition, the relatively high design values of subgrade soil characteristics make it possible to design more economical pavements. Dusty varieties of soils are not able to ensure the fulfillment of the above conditions and their use will negatively affect the reliability of highways. In subgrade working layer, it is prohibited to use silty varieties of soils, as well as heavy clays, without taking special measures to improve their deformation resistance and frost resistance. As an improvement in their work in road structure, it is recommended to use flat mattresses or geogrids placed on working layer surface, as well as enrichment with non-dusty varieties of soils.

- When using sandy loams and sandy clays in subgrade working layer in all road and climatic zones for highways of all categories, it is necessary to ensure pavement operation according to the 1st calculation scheme of moistening due to measures assigned in subgrade and drainage system design.

- The use of technogenic soils, which basically consist of soils suitable for construction, is limited. During the construction of the upper part of the subgrade, stabilization with geomaterials or replacement with debris-free soils should be envisaged if the following unacceptable content of foreign inclusions (debris) is present in technogenic soils:

- concrete and reinforced concrete scrap (with the dimensions of individual elements not exceeding $120 \mathrm{~mm}$ ) and gruss $20 \%$ or more;

- household and industrial waste $10 \%$ or more;

- organic impurities, brick breakage $5 \%$ or more.

Such limiting values of foreign inclusions are justified by the long-term practice of operating road pavements in the territories of technogenic formations. If there are heterogeneous inclusions in the technogenic soil, their total amount should not be $20 \%$ or more, taking into account the restrictions specified above. Otherwise, in the subgrade working layer there is an unacceptable concentration of volumetric forms, the behavior of which cannot be predicted over a long period of operation under the influence of temperature and humidity processes and transport effects. With a smaller amount of foreign inclusions, the technogenic soil is relatively homogeneous and stable, and when designing road pavements, it can be characterized by the indicators of the main soil in its composition.

- Inclusion of geotextile material between the surface of the subgrade and subbase layer of sand in road pavements on clay soils. In conditions of long service life, as a result of silting, the thickness of clean sand decreases, the drainage capacity of the subbase layer decreases, and the risk of developing unacceptable frost heaving increases. During the overhaul of the pavement, it is necessary to rebuild not only the bearing layers, but also the additional layers. When installing an anti-silt geotextile layer, the service life of the drainage and frost protection layers will be ensured. It is also necessary to provide for the placement of a layer of geotextile material between the subbase layer and base layer of unreinforced stone materials (Fig. 6). This measure prevents the process of embedding crushed stone material into the underlying sand layer during compaction and avoids excessive consumption of crushed stone (crushed stone-gravel-sand mixtures). Observations at the sites have shown that particles of stone material during compaction can sink into the sand layer up to $5 \ldots 6 \mathrm{~cm}$. The immersion of crushed stone particles into the upper part of the sand layer can lead to overconsumption of the base layer material of about $10-20 \%$ depending on the thickness of the base layer crushed stone particles, the mass of compaction equipment, the density of the sand layer and other factors. In addition, the 
gradual crushing of stone material leads, albeit to a slow, contamination of the sand from above due to the diffusion of the dusty fraction under the action of transport loads and gravitational waters. It should be borne in mind that the inclusion of geotextile cloths increases the design indicators and significantly reduces the cost of road pavements. As geosynthetic material between the sand and the surface of the subgrade, it is necessary to take one with a breaking load of at least $7.5 \mathrm{kN} / \mathrm{m}$ and with a static punching CBR of at least $1.0 \mathrm{kN}$. To separate crushed stone and sand, it is necessary to take geosynthetic material with a breaking load of at least $12.5 \mathrm{kN} / \mathrm{m}$ and with a static punching shear CBR of at least $1.5 \mathrm{kN}$.

- On pavements without an asphalt wear layer, protection layers and surface treatments are provided. Protective layers are one of the most effective methods for ensuring the standard service life of pavements and surface layers. In the Russian Federation, a protective layer is understood as a layer with a thickness of not more than $4 \mathrm{~cm}$, designed to protect the underlying layer of asphalt from the direct impact of road transport wheels and a complex of weather and climatic factors. The protective layer is not taken into account when calculating the structural layers of road pavements and is subject to periodic restoration during operation. According to this definition, in the practice of operating federal highways, protective layers, including thin-layer coatings, are not yet widely used. So far, the potential of protective layers to ensure the required service life of pavements and pavements is very little used.

Typical designs of pavements are divided depending on highway category, pavement type, soil type of subgrade working layer, pavement material, soil freezing average depth and traffic density class. Traffic density class of road is established according to share of trucks and buses in the total traffic intensity (Table 4).

Table 4. Traffic density classes of highways.

\begin{tabular}{|c|c|c|}
\hline \multicolumn{3}{|c|}{ Freight traffic class of highways with share of trucks and buses in traffic flow $\beta$} \\
\hline$\leq 0,25$ & $(0,25 \ldots 0,5]$ & $>0,5$ \\
\hline A & B & C \\
\hline
\end{tabular}

Traffic density class of road depends on share of trucks and buses in traffic flow $\beta$, which is determined by formula

$$
\beta=N_{t r} / N_{\text {day }}
$$

where $\quad N_{t r}$ - daily intensity of trucks and buses as part of traffic flow, vehicles / day; $N_{\text {day }}$ - total daily traffic intensity on road, vehicles / day.

An example of typical pavement designs is shown in Fig. 6.

Pavement type - permanent.

Highway category - II.

Soil of subgrade working layer is sandy loam.

Calculated humidification scheme - 1,2,3. 


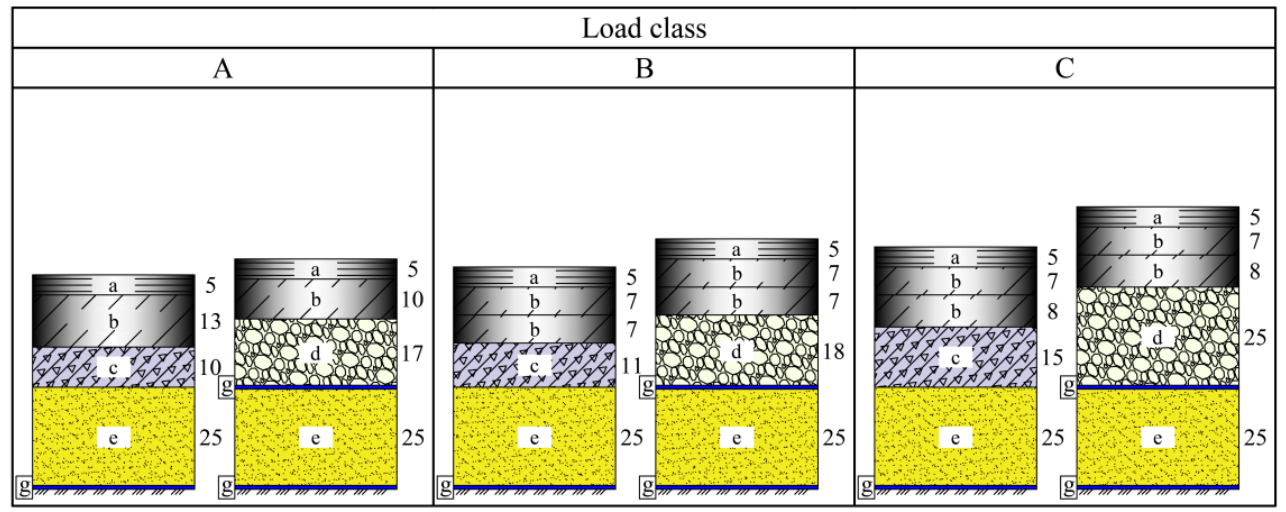

Fig. 6. Typical pavement designs for category II roads with sandy loamy sandy subgrade soil: $\mathrm{a}$ - stone-mastic asphalt; $\mathrm{b}$ - porous asphalt; $\mathrm{c}$ - binder-reinforced material; $\mathrm{d}$ - crushed stone-gravelsand mixture; $\mathrm{e}-$ sand or sand and gravel mixture; $\mathrm{g}-$ geotextile fabric.

\section{Discussion}

A rather serious problem of this study is the lack of similar work on the territory of Russian Federation. In fact, for the first time, a catalog of typical road pavements was compiled for the regional and intermunicipal road network of the Russian Federation territorial subject. It is not entirely correct to compare such typical designs with road pavements of federal roads and the road network of large cities. But it can be noted that for the most part, modern design principles are followed, which are actively implemented on the most traffic-loaded roads. At the same time, the thickness of the surface and base layers is somewhat thinner than analogs on larger routes due to the lower load density.

Typical pavement designs provide standard service life and are designed for modern standard loading parameters. They provide for the most common road building materials and work technologies in the Republic of Bashkortostan. Based on results obtained, a standard for organization of the State Committee of the Republic of Bashkortostan for transport and road facilities was prepared. Use of this organization standard will simplify procedure for development and approval of projects for construction, reconstruction and overhaul of highways, eliminate risks of making less effective engineering decisions. The catalog of typical designs of road pavements will help to determine development vector of road industry, repair to a phased transition to new road construction materials and increase standard service life of road pavements and surfaces.

\section{Conclusion}

As part of the implementation of government programs to improve and develop the road transport network of the Russian Federation, a lot of fruitful work is being done on the preparation of typical road pavement catalogs. Preparation for the direct development of typical pavements catalogs should be preceded by a detailed analysis of existing pavements in real conditions of their operation, as well as a thorough study of the quality that has a direct impact on design decisions.

Typical road pavements for the the Republic of Bashkortostan provide an opportunity to unify design solutions that simplify the assessment and analysis of the operational state of road pavements over time, as well as to form an information database on the regional road 
network, makes it possible to unify repair and restoration measures, to switch from spot correction of road pavement defects to their systematic and planned modernization.

\section{References}

1. AASHO. Guide for Design of Pavement Structures // American Association of State Highway and Transportation Officials. - Washington, DC. - 1993.

2. Book of typical road structures for Moscow city / V.V. Ushakov, Yu.E. Vasiliev, M.G. Goryachev, S.V. Lugov, E.V. Kalyonova, A.N. Kudryavtsev // Complex of urban planning policy and construction of Moscow city. - M., 2020.- 54 p.

3. Book of typical structures using Taipar SF geotextiles in construction of automobile, urban, industrial and temporary roads and improvement of urban areas. St. Petersburg, SPSUACE. 2009.

4. Catalogue des structures types de chausses neuves / Ministere de 1 Equipement des Transports et du Logement. Edition 1998. - 321 p.

5. Design of flexible road pavements. IRC 218.046-01 / Ministry of Transport of the Russian Federation. State service of road facilities. - M., 2001.- 145 p.

6. Goryachev, M.G. Application of Basic Probability Theory in Pavement quality Assessment by Layers Thickness // World Applied Sciences Journal 25 (3), 2013. - P. 481-486.

7. Guidelines for appointment of technologies and frequency of work on device of wear layers and protective layers of road surfaces. RIMD 218.3.082-2016 / Federal Road Agency (Rosavtodor). - M.; 2016.- 18 p.

8. HMA Pavement Mix Type Selection Guide / National Asphalt Pavement Association. U.S. Department of Transportation. Washington. 2001. - 25 c.

9. Kent County Council: Road Pavement Design Guide, July, 2000. - 53 p.

10. Kudryavtsev, A.N. On strength characteristics of unreinforced stone materials of base layers in design of road pavements / A.N. Kudryavtsev, S.V. Lugov, V.P. Nosov // Bulletin of MADI. Issue 4 (51), 2017.- Pp.79-84.

11. Lopashuk, V.V. Typical designs of road pavements in the northern provinces of PRC/ V.V. Lopashuk, L.V. Kormilitsyna, Ta Minyan // Transport construction. 2014. - No. 9. - Pp. 16-19.

12. Mechanistic-Empirical Pavement Design Guide. A Manual of Practice, American Association of State Highway and Transportation Officials executive committee, 2010. $-204 \mathrm{p}$.

13. Modello di catalogo delle pavimentazioni stradali. Napoli, dicembre 1993. - $46 \mathrm{p}$.

14. Neuerungen im Vorschriftenwerk. RStO12. Richtlinien für die Standardisierung des Oberbaus von Verkehrsflächen, Ausgabe, 2012. - 48 p.

15. New Zealand supplement to the document, Pavement Design - A Guide to the Structural Design of Road Pavements (AUSTROADS, 2004), 2007. - 37 p.

16. RIMD 218.2.104-2020. Book of typical designs of flexible road pavements in various road and climatic conditions / V.V. Ushakov, M.G. Goryachev, Yu.E. Vasiliev, E.M. Dobrov, V.A. Yarmolinsky, V.P. Nosov, S.V. Lugov, S.M. Dmitriev, A.N. Kudryavtsev // Federal Road Agency (Rosavtodor). - M., 2020.- 56 p.

17. RStO 11 Richtlinien fur die Standardisierung des Oberbaues von Verkehrsflachen. Ausgabe 2011. - 31 p. 
18. Standard designs catalog of flexible pavement for highways of the state company "AVTODOR". STO AVTODOR 2.25-2016. M., 2016.- 127 p.

19. The Mastic Asphalt Industry - A Global Perspective Final version IMAA / HSE Working Group March, 2013. - 30 p.

20. Ushakov V.V., Nosov V.P., Yarmolinsky V.A., Goryachev M.G., Lugov S.V. Setting Frequency of Works on the Arrangement of Wear and Protective Layers of Road Surfaces // International Journal of Applied Engineering Research, Volume 11, Number 23, 2016. - P. 1207-11214.

21. E.A. Vdovin, V.F. Stroganov and N.V. Konovalov, Nanomodified organic-inorganic polymeric binders for polymer building materials // Solid State Phenomena. 2018. Vol. 276 SSP. 223-228 p. DOI: 10.1007/978-3-030-72404-7_33

22. R. Galeev, L. Abdrakhmanova, and R. Nizamov, Nanomodified organic-inorganic polymeric binders for polymer building materials // Solid State Phenomena. 2018. Vol. 276 SSP. 223-228 p. DOI: 10.4028/www.scientific.net/SSP.276.223 